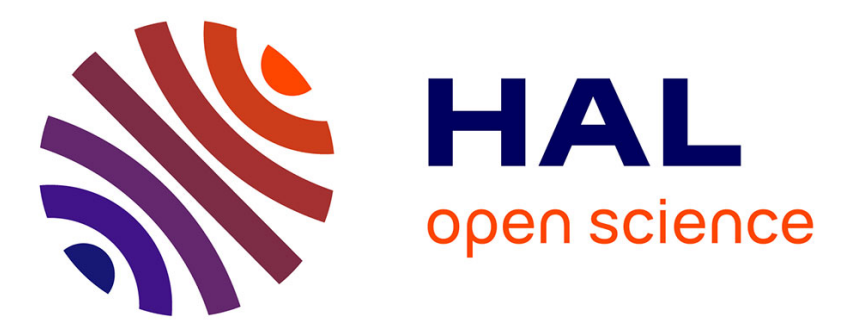

\title{
Environmental governance in the People's Republic of China: the political economy of growth, collective action and policy developments - introductory perspectives
}

\author{
Richard Balme, Tang Renwu
}

\section{- To cite this version:}

Richard Balme, Tang Renwu. Environmental governance in the People's Republic of China: the political economy of growth, collective action and policy developments - introductory perspectives. Asia Pacific Journal of Public Administration, 2014, 36 (3), pp.167 - 172. 10.1080/23276665.2014.942067. hal-02186422

HAL Id: hal-02186422

https://hal-sciencespo.archives-ouvertes.fr/hal-02186422

Submitted on 17 Jul 2019

HAL is a multi-disciplinary open access archive for the deposit and dissemination of scientific research documents, whether they are published or not. The documents may come from teaching and research institutions in France or abroad, or from public or private research centers.
L'archive ouverte pluridisciplinaire HAL, est destinée au dépôt et à la diffusion de documents scientifiques de niveau recherche, publiés ou non, émanant des établissements d'enseignement et de recherche français ou étrangers, des laboratoires publics ou privés. 
This article was downloaded by: [Richard Balme]

On: 29 September 2014, At: 02:31

Publisher: Routledge

Informa Ltd Registered in England and Wales Registered Number: 1072954 Registered

office: Mortimer House, 37-41 Mortimer Street, London W1T 3J H, UK

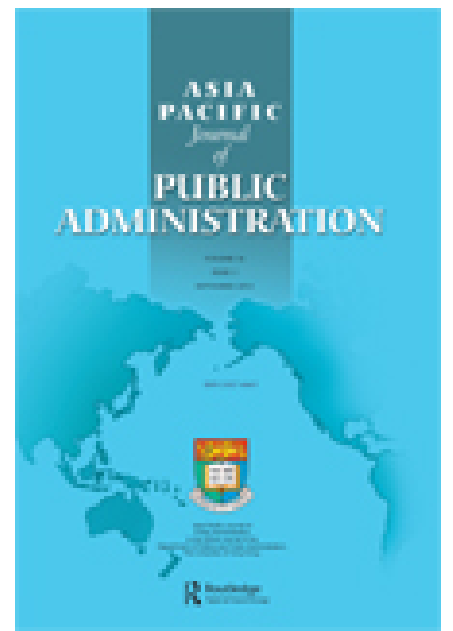

\title{
Asia Pacific J ournal of Public Administration
}

Publication details, including instructions for authors and subscription information:

http:// www.tandfonline.com/loi/ rapa20

\section{Environmental governance in the People's Republic of China: the political economy of growth, collective action and policy developments - introductory perspectives}

\author{
Richard Balme ${ }^{a} \&$ Tang Renwu ${ }^{b}$ \\ ${ }^{a}$ Sciences Po, Paris School of International Affairs and Centre for \\ European Studies, Paris, France \\ ${ }^{b}$ School of Government and Academy of Governance, Beijing \\ Normal University, Beijing, China \\ Published online: 24 Sep 2014.
}

To cite this article: Richard Balme \& Tang Renwu (2014) Environmental governance in the People's Republic of China: the political economy of growth, collective action and policy developments - introductory perspectives, Asia Pacific J ournal of Public Administration, 36:3, 167-172, DOI: 10.1080/23276665.2014.942067

To link to this article: http:// dx. doi.org/ 10.1080/23276665.2014.942067

\section{PLEASE SCROLL DOWN FOR ARTICLE}

Taylor \& Francis makes every effort to ensure the accuracy of all the information (the "Content") contained in the publications on our platform. However, Taylor \& Francis, our agents, and our licensors make no representations or warranties whatsoever as to the accuracy, completeness, or suitability for any purpose of the Content. Any opinions and views expressed in this publication are the opinions and views of the authors, and are not the views of or endorsed by Taylor \& Francis. The accuracy of the Content should not be relied upon and should be independently verified with primary sources of information. Taylor and Francis shall not be liable for any losses, actions, claims, proceedings, demands, costs, expenses, damages, and other liabilities whatsoever or howsoever caused arising directly or indirectly in connection with, in relation to or arising out of the use of the Content.

This article may be used for research, teaching, and private study purposes. Any substantial or systematic reproduction, redistribution, reselling, loan, sub-licensing, 
systematic supply, or distribution in any form to anyone is expressly forbidden. Terms \& Conditions of access and use can be found at http://www.tandfonline.com/page/termsand-conditions 


\title{
Environmental governance in the People's Republic of China: the political economy of growth, collective action and policy developments - introductory perspectives
}

\author{
Richard Balme ${ }^{\mathrm{a} *}$ and Tang Renwu ${ }^{\mathrm{b}}$ \\ ${ }^{a}$ Sciences Po, Paris School of International Affairs and Centre for European Studies, Paris, \\ France; ${ }^{b}$ School of Government and Academy of Governance, Beijing Normal University, \\ Beijing, China
}

(Received 8 June 2014; accepted 24 June 2014)

\begin{abstract}
The special issue is introduced here by considering the state of the environment and environmental governance in the PRC. While significant, substantial developments in legislation and policymaking remain insufficient to tackle the degradation of the environment and the increasing saliency of environmental issues in Chinese politics. Tremendous challenges remain in the areas of natural resources governance, environmental health, and transition paths in agriculture and urban development. They need to be addressed by an even stronger commitment of the Chinese leadership, accompanied by significant reforms in the areas of environmental litigation, the transparency of local government decision-making, and the capacity of the self-organisation of Chinese citizens in mobilising on environmental issues.
\end{abstract}

Keywords: China (PRC); environmental governance; environmental policy; environmental challenges

\section{Introduction}

There is very little controversy about the extent of current challenges raised by environmental issues in the People's Republic of China (PRC). The reform policy launched in 1978, triggering intensive economic growth over more than three decades, has entailed massive industrialisation, urbanisation and the use of natural resources. The participation of China in the world economy and its active role in globalisation enabled this astonishing record of development, lifting many millions people out of absolute poverty. With such a rapid change, however, the use of land, water resources, energy and raw materials, as well as the impact on the environment and ecosystems, became unprecedented - as acknowledged by the annual reports on the state of the environment released by the Ministry of Environment Protection.

Chinese cities rank among the most affected by air pollution by international standards, while water basins suffer from severe situations, frequently entailing direct threats to the health of residents. "Cancer villages", where local contamination of soil and water by heavy metals has disastrous consequences for local communities, are widely reported. A large proportion of rainfall consists of acid rain. Industrial accidents are noticeably frequent, and food safety is affected by environmental degradation through soil and water contamination. $\mathrm{CO} 2$ and more widely greenhouse gas emissions

*Corresponding author. Email: richard.balme@sciencespo.fr 
by China have overpassed all other countries since 2008. Biodiversity is not at rest, with severe impacts on marine and coastal ecosystems where the bulk of Chinese growth is located, desertification in the north, and investment and exploitation of resources in the west.

The poor, being the section of the population with the lowest standards of living, are the most affected by environment depravation, thereby contributing to social inequalities. Severe industrial pollution accidents, together with land use disputes and corruption cases, are among the major motives for eruptive protests and social mobilisation regularly affecting the PRC rural areas. In addition, projections established by global warming experts indicate that China is likely to suffer the effects of climate change very significantly in the coming decades, with more frequent occurrence of typhoons, a rise of sea levels affecting coastal areas, and more intensive desertification in the north affecting food security. The existing natural fragilities of China's environment are severely threatened by the intensity and brutality of the country's development.

\section{Environmental challenges, concerns and initiatives}

Environmental problems as such are a set of stringent policy challenges for Chinese authorities. The capacity to prevent and to react to environmental challenges largely questions the legitimacy of governments at the local level, as exemplified by the numerous cases of environmental protests over the last two decades. In 2012, Yang Chaofei, the vice-chairman of the Chinese Society for Environmental Sciences, recorded in a lecture organised by the Standing Committee of the National's People's Congress on the social impact of environmental problems that the number of environmental "mass incidents" grew by an average of 29\% annually from 1996 to 2011, and $120 \%$ from 2010 to 2011 . Yang also said that the number of incidents involving concerns about dangerous chemicals and heavy metal pollution have risen since 2010.

The results of a 2012 survey indicated that the number of such incidents is not likely to decrease any time soon (China Times, 30 October 2012). In a strong sign that the Chinese public is not going to remain unheard, $78 \%$ of those surveyed said that they would participate in protests if polluting facilities were to be built near their homes.

The situation is now more severe than a mere accumulation of stringent local problems. Systemic and large scale environmental problems embodied in the alarming condition of water quality, of food safety, and of air pollution in major cities significantly impact everyday life and public health of the population nationwide. Such policy failures openly challenge the capacity of the "market socialism" approach to development to offer better living conditions and to secure personal safety for Chinese citizens.

Yet the reality of the development of the PRC's environmental policy is not as dark as the idea of a "dirty growth" model sometimes suggests. Significant legislative, regulatory, and institutional developments have occurred in the last decades (Ma \& Ortolano, 2000; Sinkule \& Ortolano, 2005; Lo \& Tsang, 2013). Since 2008, China has had a full Ministry of Environment Protection (formerly the State Environmental Protection Administration SEPA) as a cabinet-level ministry directly under the State Council in charge of implementing environmental policies and enforcing environmental laws and regulations. Since 2006, five regional centres have monitored local inspections and enforcement. Environmental protection ministries exist at the provincial level, along with environmental protection bureaus at the township and county levels. 
The PRC adopted a Law for Environmental Protection as early as 1989, followed and backed by numerous more specific legislation in such areas as water, pollution discharge, air quality, forestry, and waste. The 1989 law was revised through a long drafting process to make it more stringent; and after President Xi Jinping declared war on pollution during the opening of the National People's Congress in March 2014, the legislative branch of the government approved a new environmental law in April 2014 to become effective in January 2015. The law grants environmental enforcement agencies greater punitive power, defines areas which require extra protection, and gives independent environmental groups more ability to operate in the country. In June 2013, the supreme court even issued a ruling expanding the use of the death penalty in the more severe cases of pollution.

Most of the country, down to the county level at least, is covered by a set of homogeneous and reasonably consistent regulations and administrative units in charge of environmental issues. The new leadership established by the 18th Party Congress in December 2013, following his predecessors, widely acknowledged the importance of environmental issues and pledged to orient the country towards an "ecological civilization".

The media, as well as a significant number of remarkably active NGOs and the public in general, are particularly sensitive and mobilised on environmental issues. China Daily reporting on a survey released in 2013 indicated that nearly $80 \%$ of Chinese residents believe that environmental protection should be a higher priority than economic development. Nearly half the respondents said the government should spend more on environmental protection. Some $67 \%$ said they would like to improve the water environment through donations, taxes and increased water cost. Overall satisfaction with the government's performance on the environment is poor. Over $60 \%$ said government information about environmental protection is not transparent ${ }^{1}$.

China's environmental policy today remains limited in its effectiveness, for a number of reasons characteristic of the loopholes in its governance structure. The infamous "implementation gap", regularly identified in the policy literature (Lampton, 1987; Lieberthal \& Oksenberg, 1988), refers to the discrepancy between national objectives and legislation and their territorial transcriptions, particularly at the sub-provincial level. Several causal factors are relevant to explain this situation. Among them are the lack of vertical coordination in the environmental (as well as general) bureaucracy and the de facto limited authority of local environment protection bureaus; the considerable dominance of growth objectives translated into industrial and urban construction policies over environment protection at the local level; the current political economy of China and more precisely the fiscal structure of the government which urges local authorities to develop fiscal resources through growth policies; the resulting growth coalitions bringing together political leadership, local governments and business interests, cemented by social networks largely initiated and controlled by the CCP at the local level; the limited capacities of the media and NGOs to act independently and to challenge public authorities when they fail to protect the environment; and the absence of a separation of powers and the de facto submission of local courts to local governments, severely limiting the capacity for effective litigation on environmental issues.

Policy developments are limited in their effectiveness by top-down as well as bottom-up constraints. In such a context, where can policy innovation come from? Can there be any policy learning and institution building progressively promoting and consolidating the capacity for environmental protection? 


\section{The discussions ahead}

Given the situation described above, the definition of environmental rights and the procedures of environmental litigation are of critical importance. Thus, Balme provides an assessment of environmental rights in China and analyses the political interactions supporting their definition and implementation. The discussion shows that the development of legislation, collective action, public participation and litigation have served as converging factors to allow for some significant improvements in environmental policymaking over the last decade. Although these innovations remain far from reversing the general state of the environment in China, they have introduced more participative and less arbitrary patterns of interaction among policy stakeholders. They have contributed to a more open and fair policy process, which has fuelled demands and expectations for environmental justice. The long-term effects of these tendencies, however, remain dependent on the reorientation and commitment of the PRC's leadership to a more sustainable pattern of development and to providing the political conditions for its implementation.

A particularly important challenge for policy development and implementation involves social mobilisation, with environmental protests in China having been largely reported and studied ${ }^{2}$. Here, Lian provides a significant case study of the resistence of farmers regarding land expropriation. As the political economy of growth in China translates into a vast urbanisation process, the expansion of cities gives rise to a reallocation of land use, a transfer of property rights, and a transformation of social status for millions of farmers, conducted under the rule of local governments. Consequently, the relations between land-lost farmers and urban government are highly intricate. If tackled imprudently, serious social or even political problems may emerge. The analysis shows that land-lost farmers tend to appeal to government through the system of letters and visits. The various types of appeals to the government from land-lost farmers can be considered as an endeavor to have their rights acknowledged. According to their reports, the consciousness of their rights not only derives from their nostalgia for established life-styles, but also involves their reflections after comparing expectations and realities, the regulations released in official documents, and differences across villages and localities. Farmers respond to the marketisation of land by arguing that the administration in the new system still has moral obligations to them. They do not call into question the authority of the CCP or its ideology, but they do make use of such authority and ideology to add legitimacy to their own appeals and resistance. Over time, changes in the government's working strategies have corresponded to the resistance of land-lost farmers, with a gradual transition from limitless power to relatively more restricted forms of authority. The changing use of land as a natural resource has served as a key driver to transform the social structure and to define motives and modes of contention with public authorities.

Critical for understanding the nature and significance of particular policy developments, Jia explores the question of international influence in norm-setting and environmental policy transfers in China. Scholarly attention on international norms diffusion and policy learning asserts that international influence could have a positive impact on China's environmental politics. However, the policy process in China still remains to a large extent structured by the campaign style dating back to Mao's era. A case study of two inland counties in Shaanxi province challenges the so-called international influence approach. Both counties involved in international forestry cooperation with Germany indeed learnt from their partner in implementing the Grain for Green project, but with 
different levels of subsequent institutional change. Clearly, the presence of a strong learning agent is a decisive condition for the effectiveness of knowledge dissemination and policy transfer. The analysis shows that international influence cannot contribute to domestic governance independently of local conditions, and that the latter remain decisive for innovation in environmental policymaking.

Whether in opposition or in parallel to policy learning and social mobilisation, some patterns of environmental governance can emerge "bottom-up", based on spontaneous forms of collective action rooted in social networks of trust and cooperation. Can self-governance contribute to environmental problems, and particularly to the management of natural goods when they are used as common pool resources? In response, Wang, Shao and Cai present a case study of pasture management in Gansu province, a north-west province of China severely affected by desertification. Based on observations, they contest the possibility of such arrangements emerging because of the absence of critical conditions, namely the existence of gradual sanctions and minimal rights for herders to self-organise. The conclusions provide substantial lessons for policymakers.

Agriculture involves questions of food security and food safety which are strong incentives to modernise the sector and to orient it towards more sustainable patterns of production. In a study conducted in Beijing, Shanghai and Jiangxi province, Schwoob shows that relationships established in rural areas are key elements for the successful implementation of agricultural change. Strategies implemented by local governments to encourage more modern and more sustainable practices in the agricultural sector rely on food and retail enterprises. Such strategies have evolved in a real modus operandi which is close to strategies implemented by developmental and corporatist states, but with more complex forms of state integration in the economy. The analysis considers how stakeholders who might be able to provide answers to environmental issues in the agricultural sector are locked into a rigid state enterprise nexus as well as in path dependencies and cultural constraints. The over-reliance of local governments on state enterprises could delay a more sustainable pattern of farming practices.

In the face of increasing environmental pollution and a rapid pace of urbanisation, sustainable urban development nowadays becomes a more and more important issue for China. As the country's urbanisation level rises to $70 \%$ by 2035 , the way its cities develop and the control over resources consumed for this growing urban activity are of paramount importance. Despite a rhetoric pushing for the realisation of sustainable cities, urban development practices persistently show a different picture, casting doubts over the effectiveness of policies adopted at the different levels of government. In this regard, Romano shows how the different dimensions of environmental management concerning sustainable urban development policies still encounter important obstacles to their implementation. Notwithstanding the adoption of policies and regulations for sustainable urban development, the trajectories of Chinese cities are still characterised by a prioritisation of economic growth (led by urban expansion) to environmental concerns and an ineffective management of environmental issues (and related domains), confirming a picture described by scholars in the 1990s. With reference to a series of programmes, policies and regulations issued on the different topics of urban sustainability, namely the building sector, the urban planning sector, the transportation sector and the urban solid waste and wastewater management sectors, a sceptical assessment is provided of their performance, casting doubt over the capacity of urban policy to overcome its institutional, socio-economic and political constraints and take a more sustainable turn. 


\section{Concluding comments}

The overall picture provided by the following articles is, not surprisingly, critical of the state of the environment and of the capacity of environmental policy to reverse significantly what is already a long term trend. Despite the urgency of the situation and substantial policy programmes in most important areas, better environmental conditions, if any, can only be expected in the medium or long term. In many respects, the limits of environmental policy in China are similar to what they are in most developed countries, with partial and delayed performances but in a more serious and challenging context. In many sectors, Chinese policy initiatives will need to be bolder, and the government will have to prioritise their implementation. It will also need to provide the conditions for their success, namely to develop the transparency and accountability of local governments in urban and industrial policy, to ensure more independence of the judiciary and the media, and to allow people the right to self-organise to manage natural resources.

\section{Acknowledgement}

Some of the articles in this special issue were initially presented at an International Conference on Public Policy held at the Academy of Governance at Beijing Normal University, 5-7 June 2013. We wish to thank the University of Chester, Seoul National University and the University of Hong Kong for co-organising the conference. We are particularly grateful to Dr Guo Jia for her help in the organisation of the conference and for subsequent editorial assistance.

\section{Notes}

1. The survey, conducted by the Pubic Opinion Research Center under Shanghai Jiao Tong University, aimed to find out residents' attitudes toward the country's environmental protection and how they rate the government's performance. It was conducted among 3,400 residents from 34 cities through computer-aided telephone interviews in March and April 2013.

2. Among many other cases, the protest in Kunming in 2013 opposing a petrochemical plant to produce paraxylene (PX) was widely reported. The same year a thousand people took to the streets in the Songjiang district of Shanghai against plans for a lithium battery factory amid concerns about water and air pollution. The plans were eventually canceled by the authorities.

\section{References}

Lampton, D. (1987). Policy implementation in Post-Mao China. Berkeley: University of California Press.

Lieberthal, K., \& Oksenberg, M. (1988). Policy making in China: Leaders, structures, and processes. Princeton, NJ: Princeton University Press.

Lo, C. W., \& Tang, S. (2013). Institutions, Regulatory styles, society and environmental governance in China. London: Routledge.

Ma, X., \& Ortolano, L. (2000). Environmental regulation in China: Institutions, enforcement, and compliance. Lanham, Maryland and Oxford: Rowman \& Littlefield.

Sinkule, B. J., \& Ortolano, L. (2005). Implementing environmental policy in China. Westport: Greenwood Publishing. 